\title{
Characterising Local Knowledge across the Flood Risk Management Cycle: A Case Study of Southern Malawi
}

\author{
Robert Šakić Trogrlić ${ }^{1, *(D)}$, Grant B. Wright ${ }^{1} \mathbb{1}$, Melanie J. Duncan ${ }^{2}$, \\ Marc J. C. van den Homberg ${ }^{3}{ }^{(}$, Adebayo J. Adeloye ${ }^{1}{ }^{1}$, Faidess D. Mwale ${ }^{4}$ and \\ Joyce Mwafulirwa ${ }^{5}$ \\ 1 School of Energy, Geoscience, Infrastructure and Society, Heriot-Watt University, Edinburgh EH14 4AS, UK; \\ g.b.wright@hw.ac.uk (G.B.W.); a.j.adeloye@hw.ac.uk (A.J.A.) \\ 2 British Geological Survey, The Lyell Centre, Edinburgh EH14 4AP, UK; md@bgs.ac.uk \\ 3510 An Initiative of The Netherlands Red Cross, 2593 HT The Hague, The Netherlands; \\ MvandenHomberg@redcross.nl \\ 4 Department of Civil Engineering, University of Malawi, The Polytechnic, Blantyre 3 P/Bag 303, Malawi; \\ fmwale@poly.ac.mw \\ 5 Total Malawi Limited, Limbe, Blantyre P.O. Box 5125, Malawi; joycemwafulirwa@gmail.com \\ * Correspondence: rs36@hw.ac.uk
}

Received: 26 February 2019; Accepted: 15 March 2019; Published: 20 March 2019

check for updates

\begin{abstract}
People possess a creative set of strategies based on their local knowledge (LK) that allow them to stay in flood-prone areas. Stakeholders involved with local level flood risk management (FRM) often overlook and underutilise this LK. There is thus an increasing need for its identification, documentation and assessment. Based on qualitative research, this paper critically explores the notion of LK in Malawi. Data was collected through 15 focus group discussions, 36 interviews and field observation, and analysed using thematic analysis. Findings indicate that local communities have a complex knowledge system that cuts across different stages of the FRM cycle and forms a component of community resilience. LK is not homogenous within a community, and is highly dependent on the social and political contexts. Access to LK is not equally available to everyone, conditioned by the access to resources and underlying causes of vulnerability that are outside communities' influence. There are also limits to LK; it is impacted by exogenous processes (e.g., environmental degradation, climate change) that are changing the nature of flooding at local levels, rendering LK, which is based on historical observations, less relevant. It is dynamic and informally triangulated with scientific knowledge brought about by development partners. This paper offers valuable insights for FRM stakeholders as to how to consider LK in their approaches.
\end{abstract}

Keywords: local knowledge; flood risk management; community-based disaster risk reduction; disaster risk reduction; early warning; early action

\section{Introduction}

Disasters are a consequence of vulnerability created through political, social and economic environments, rather than simply the result of natural hazards [1-3]. In developing countries, high levels of poverty allied to a lack of access to land and employment, often drive people to settle in zones that are highly exposed to natural hazards. On a global scale, poor people are twice as likely to live in dwellings that are vulnerable to natural hazards [4], and current projections indicate that, by 2030, there could be up to 325 million extremely poor people (i.e., on less than $\$ 1.25$ per day) living in locations that are most exposed to natural hazards [5]. 
Vulnerable populations have devised a creative set of strategies and complex adjustments that have allowed them to live in hazard-prone areas, and they possess invaluable local knowledge (LK) that has helped them to prepare and manage crises caused by natural hazards [6-8]. LK includes knowledge of hazards, vulnerabilities and capacities [8], is an inherent part of community resilience and capacity $[9,10]$ and is a basis for local coping strategies [11]. Through application of LK, communities are able to help themselves in the absence of, and prior to the arrival of, external parties [12]. LK is especially valuable for communities exposed to recurrent flooding, who have developed culturally embedded knowledge on how to live with floods over many generations [13].

The 1980s and 1990s saw a paradigm shift from top-down, and technocratic approaches to development and disaster risk research and practice, to more bottom-up, people-centred, and participatory approaches [14-18]. Although these changes opened the door for increased attention to LK, due to its focus on putting communities at the centre of DRR, the topic of LK was not extensively covered in the disaster literature [19] until the 2004 Indian Ocean Tsunami, when local responses that helped indigenous communities to survive were widely shared, sparking research and policy interest in LK $[7,20,21]$. Subsequent literature on the subject recognises many benefits in using LK for DRR, including: helping to address local needs; improving planning and implementation; increasing project performance and acceptance; contributing to sustainability and cost-effectiveness; creating trust, ownership, and increased self-confidence in communities [22,23].

However, LK is not without its limitations [24,25]. For instance, research by Hooli (2016) [26] argues that a focus on LK in resilience building strategies might shift attention away from the broader socio-economic processes that determine vulnerabilities. Another limitation is that LK is under pressure from global environmental, climatic and socio-economic changes (such as urbanisation, climate change, deforestation, population pressure and globalisation) that might undermine its applicability [27-29]. Finally, LK might not be applicable to extreme events that are outside the lived experiences of communities [8].

Both the benefits and limitations of LK, as described above, call for a closer integration of local and scientific knowledge [22,30-34], and the creation of integrated knowledge as a base for improved decision making in DRR [7]. Integration is seen as a way of 'banking' on the strengths of both local and scientific knowledge; as argued by Mercer [35]: 'the limitations of outside knowledge could be addressed through the strengths of local knowledge and vice versa.'

Despite the recognised benefits of LK and its increasing recognition in disaster research and practice, it is generally seen as being inferior to technical solutions (based on scientific knowledge) by mainstream development practice $[11,35,36]$. As such, it is often overlooked and underutilised by stakeholders who are involved in existing approaches to flood risk reduction and management at local levels [35]. This reticence is partly due to the lack of a real evidence base to demonstrate the utility of LK, and there are thus increasing calls for its identification and documentation [37]. These calls have been mirrored in international policy agreements through the Hyogo Framework for Action 2005-2015 [38] and the Sendai Framework for Disaster Risk Reduction 2015-2030 [39], which both advocate the wider recognition and use of LK.

\section{The Context of Malawi}

Malawi is a small, landlocked country in Sub-Saharan Africa, ranked as the third poorest in the world [40]. Malawi's economic situation is in no small part due to flooding, the impacts of which effectively stifle development. Rural communities in Malawi are particularly vulnerable to floods [41], which negatively impact livelihoods, infrastructure, and local communities' social, economic, cultural, and psychological values [42]. In addition to typical annual flooding, 2015 saw unprecedented extreme flooding, which caused estimated losses of $\$ 335$ million, affecting 1.2 million, displacing 230,000, and causing around 170 fatalities [43,44].

Previous research on flooding in Malawi has predominantly focused on identifying current deficiencies in the way in which flood risk management (FRM) is planned and implemented 
(e.g., [42,45-48]). In the existing system, the central government does not have the capacity to facilitate and deliver risk reduction at the local scale, primarily due to a lack of dedicated funding sources [49]. Hence, disaster risk reduction (DRR), including FRM, is predominantly led and implemented by non-governmental organisations (NGOs) through community-based approaches $[47,50]$. These approaches rely on the LK that communities possess, to help to ensure sustainable, locally accepted and locally owned interventions [51,52]. However, recent studies from Malawi indicate that community participation, a prerequisite for successful community-based flood risk management (CB-FRM) and inclusion of LK, is currently inadequate. For instance, while researching flood vulnerability in Nsanje, Chawawa [53] reported that over $90 \%$ of households surveyed were not involved in the design of any FRM projects, with those consulted being influential individuals within communities (e.g., members of the Village Civil Protection Committees (VCPCs), chiefs). Šakić Trogrlić et al. [47] also reported examples from the Lower Shire Valley, where communities expressed a lack of satisfaction with their involvement in project implementation. Currently, it would appear that community participation is limited to working with VCPCs, which are predominantly established in areas where NGOs have active projects, but these often cease to function after the project ends, and they involve the issue of power relations and elite capture at local levels.

The current levels of community participation indicate that LK is not being effectively used in the design and implementation of FRM projects within Malawi. This lack of inclusion of LK is also evident at policy levels where, despite the importance placed on LK by the Sendai Framework for Disaster Risk Reduction (especially under Priority 1: Understanding Disaster Risk) [39], there are no substantially explicit references to LK in the Malawi National Disaster Risk Management Policy [54]. Similarly, there is little reference to LK in local government contingency plans [55,56], and LK is not integrated into local level disaster planning [46].

As argued in the literature, there is a need to develop an understanding of and to create an evidence base for LK before it can be effectively used in decision-making processes and policy levels (e.g., [7,33]). Unlike many Asian countries [37,57-60], this evidence base is virtually non-existent for much of Africa [11,28,61,62], with previous studies in Malawi [41,45-47,63-66] merely acknowledging the existence and importance of LK, without any deeper understanding of what constitutes LK. Given that African countries are experiencing the impacts of global changes, it is important to take a step further from mere documentation of LK and critically assess its reality and potential role for DRR. The present study contributes to these knowledge gaps by critically engaging with the concept of LK and its dynamics in the most flood-prone areas of Malawi (the Lower Shire Valley).

The remainder of this paper is organised as follows: a brief overview of the concept of LK and its rising prominence in disaster studies, a description of the qualitative methodological approach adopted, a presentation of the different dimensions of LK for FRM, and finally, a discussion of the results and main conclusions.

\section{Conceptualising Local Knowledge in Disaster Risk Reduction}

Broadly speaking, LK is 'the knowledge that people who live in a particular place have about their area' [24], p. 595, and it is 'knowledge that has evolved within (inside) a specific community or area, but that has potentially incorporated or been shaped by outside knowledge in its continuous evolution' [35], p. 99. A number of terms for LK are commonly found in the literature (e.g., 'indigenous knowledge', 'traditional knowledge', 'traditional ecological knowledge' 'rural people's knowledge', 'indigenous technical knowledge', 'traditional environmental knowledge', 'folk knowledge', 'people's science', 'folk science') $[22,27,35,67,68]$, and the application of a specific term seems to depend on academic discipline, context and language [8]. This paper deems the term "LK" to be the most appropriate term, due to several reasons:

1. the acknowledgment that conceptually broader terms such as LK provide a more comprehensive depiction of a phenomena [28,69], 
2. the characteristics of the case study area (e.g., high presence of development partners and penetration of modern technologies), and

3. the vagueness and political connotations of the term 'indigenous knowledge', and its perceived spatial and temporal continuity, whilst in reality, it hardly exists in intact form $[25,59,60,68]$.

This research therefore conceptualises that LK 'encompasses the knowledge and practices that are acquired by local people over a period of time through the accumulation of experiences over generations, society-nature relationships, and community practices and institutions' ([23], p. 38, similar to $[30,61])$. In addition, conceptualisation in this research is further expanded to include both the 'traditional' and 'new' experimental knowledge produced and applied by local people [70]. Simplified, LK is what communities know about natural hazard related risks, how they perceive these risks, and what actions they take to address them [22].

Several characteristics of LK deserve special attention:

- Its informality; LK is orally transmitted (from generation to generation), and is largely undocumented; it is based on experimentation, adaptation and innovation, and it is driven by the pragmatic demands of everyday life [12,20,25,71].

- LK is context-based, embedded into practices, specific to communities and environments and varies between different localities in time and space; it therefore cannot be detached from its immediate social and political realities $[25,26,58,72,73]$. Its local character is what gives it agency, power and relevance [25].

- Despite common misconceptions, LK is anything but static; it is fluid and continuously evolving both as the needs and experiences of local people change, and through exposure to external knowledge systems $[36,58,67,73,74]$. This dynamic nature is exemplified in the concept of 'hybridisation' where LK is continuously negotiated, fed, co-produced and intertwined with 'Western', 'scientific' or 'external knowledge' [7,25,26,30,59,75]. As discussed by Mercer (2012) [35], communities are pragmatic and opportunistic in assessing what external knowledge is appropriate for local usage.

- LK is not homogenous and it is not a community trait (for a discussion of the contentious concept of 'community' in development and DRR, see [76]). Among others, factors such as age, gender, power status, poverty levels, and social grouping create diverse sets of knowledge within a community, and condition access to LK and its use [22,25,58,69,77]. Hence, any meaningful involvement with LK cannot ignore the issues of local power relations and hegemony $[24,25,59$, $78,79]$.

\section{Research Approach}

With the aim of providing an in-depth understanding of the realities of LK in flood-prone communities, the research adopted a qualitative research framework (Figure 1) using interpretivist research philosophy (e.g., [80]). Taking into account the fact that context is key for LK, a case-study research design was employed (e.g., [81]). The research was conducted in the Lower Shire Valley (composed of Chikwawa and Nsanje districts), the most flood-prone area of Malawi [82], exposed to annual flooding and with a presence of highly vulnerable communities [41]. Primary data was gathered between June and August 2017 through gender-separated focus group discussions (FGDs), key informant interviews (KII) and field visits (Table 1), which enabled triangulation. 


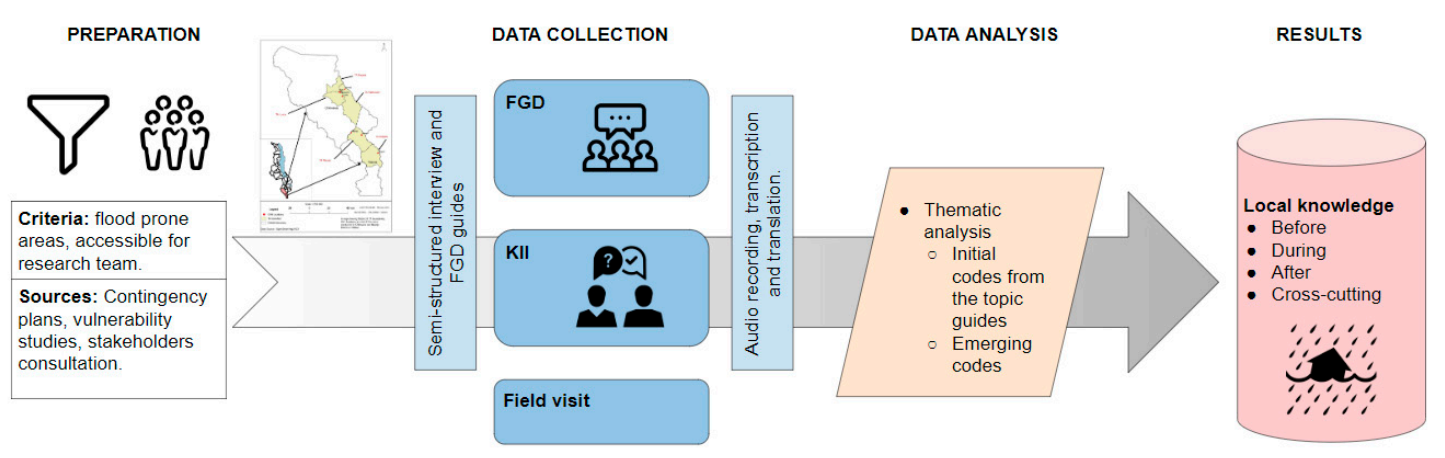

Figure 1. Qualitative research framework.

Table 1. Overview of focus group discussions (FGDs) and key informant interviews (KIIs).

\begin{tabular}{cccccc}
\hline Districts & Group Village Head (GVH) & FGD M & FGD F & KII M & KII F \\
\hline Chikwawa & Tizola * & 7 & 5 & - & - \\
& Kanseche & 7 & 5 & 5 & 4 \\
Misli & 8 & 8 & 4 & 2 \\
& Mmodzi & 8 & 8 & 3 & 2 \\
& Area Civil Protection & 7 & 3 & - & - \\
\hline Nsanje & Ccommittee Maseya * & & & & \\
& Mbenje & 8 & 8 & 4 & 1 \\
& Nyanga & 8 & 8 & 3 & 2 \\
& Tengani & 7 & 7 & 4 & 2 \\
& ACPC Tengani * & 6 & 2 & - & - \\
\hline & Total per gender & $\mathbf{6 6}$ & $\mathbf{5 4}$ & $\mathbf{2 3}$ & $\mathbf{1 3}$ \\
\hline
\end{tabular}

* FGDs in Group Village Head (GVH) Tizola, and with Area Civil Protection Committees (ACPCs) in Maseya and Tengani were not gender-separated. This was due to the fact that GVH Tizola served as a pilot community, while ACPCs are community institutional structures with mixed gender membership.

The criteria for the selection of communities were: (i) communities located in flood-prone areas, and (ii) communities accessible for the research team. Initial case study communities were identified through District Contingency Plans [55,56], previous studies on flood vulnerability [41], and consultation with local stakeholders (local governments and NGOs). The resulting shortlist of communities was then further refined in discussions, both with an international consultancy team working on a local flood risk reduction project, and with local government staff. Finally, six communities were selected, with an additional community (i.e., GVH Tizola) being used to pilot the FGD questions (Figure 2). Additionally, the research team had visited two Area Civil Protection Committees (i.e., community representatives at the Traditional Authority (TA) level) in the TAs Tengani and Maseya.

In total, 15 FGDs and 36 KIIs were conducted involving village heads, members of the Village and Area Civil Protection Committees, Village Development Committees, elderly community members, religious leaders, lead farmers, youth representatives and regular community members. The participants were selected purposively in consultation with village heads, using the following criteria: (i) over 18 years of age, (ii) living in the community for a 'long' period of time (preferably longer than 20 years), (iii) experience with flooding, and (iv) living or farming in the low-lying, flood-prone areas. Questions were open-ended and designed to capture multiple aspects of LK (Supplementary Material). Typical questions asked were:

- What is the LK that community members use before, prior to and during flooding?

- How is LK learned and disseminated in the community?

- Do different community members have different LK?

- Is there a difference in the use of LK now when compared to the past? 


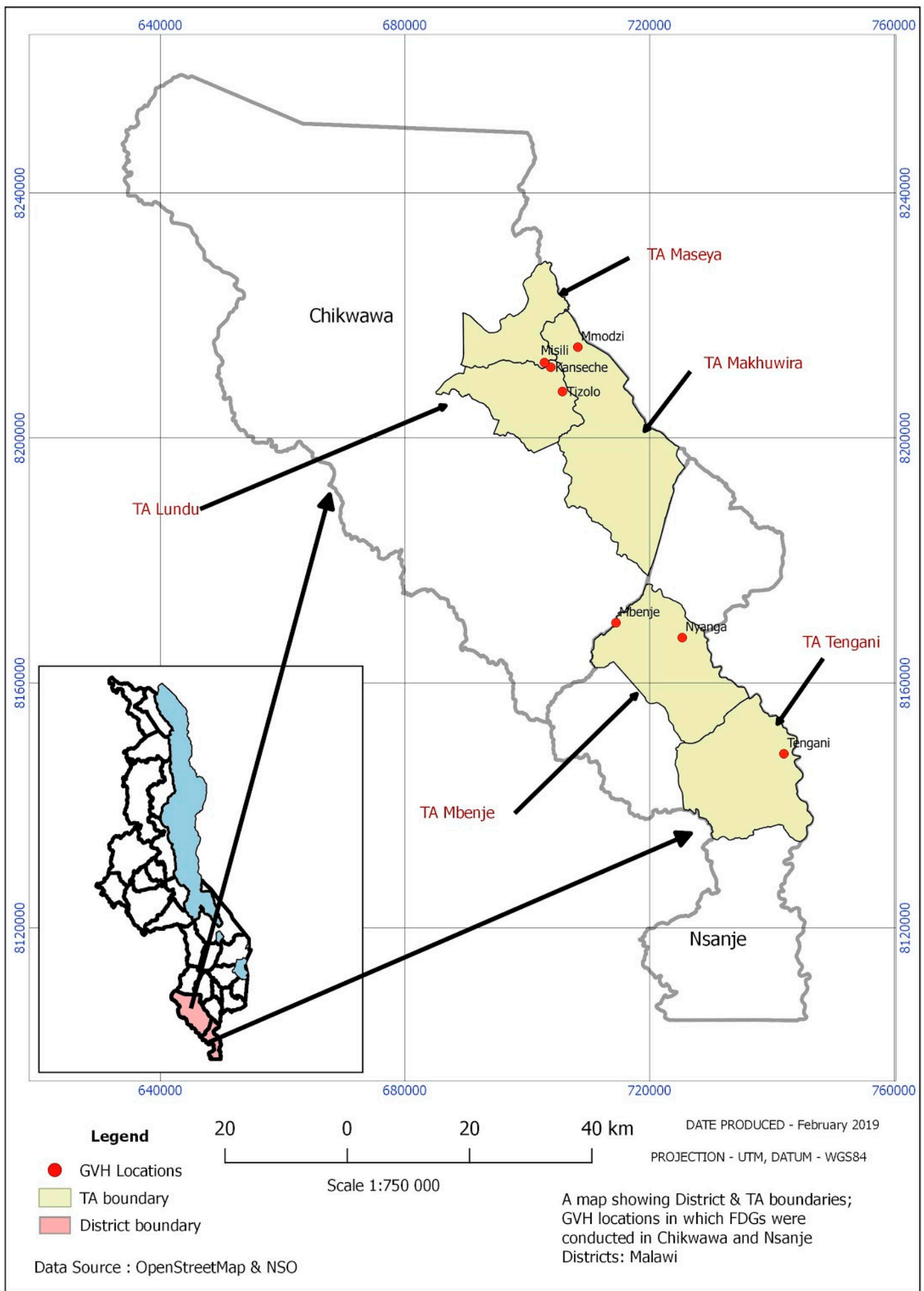

Figure 2. Location of the case study areas.

Similar questions were asked during both FGDs and KIIs, allowing for a direct comparison of the use of LK at the individual and community scale, and in order to avoid potential biases of basing the findings on a sole data collection method. The gender-separated approach was followed, to identify gendered dimensions of LK, which are largely overlooked in disaster studies on LK (e.g., [59]). All the FGDs and KIIs were conducted in the communities in which the participants resided. Having a 
relatively large sample for a qualitative study made it possible to capture the richness and the diversity of LK in the area, and also meant that data saturation was reached.

All of the FGDs, and all but two KIIs were conducted in Chichewa or Sena. All FGDs and KIIs were audio recorded and transcribed, with translation to English and the facilitation of discussions being provided by Malawian members of the research team. The data collected during FGDs and KII were coded and analysed using thematic analysis [81]. The initial list of codes was created based on the topics covered in the interviews and FGDs with further codes emerging through the process of analysis. Transcripts were organised and analysed using NVivo 11 [83].

\section{Dimensions of Local Knowledge for Flood Risk Management in the Lower Shire Valley}

The empirical findings of this study indicate that LK is present across the different stages of the flood risk management cycle (i.e., before, during and after the flood: phases commonly used in disaster research e.g., [84]), resulting in a multidimensional and complex knowledge system, conceptually presented in Figure 3, which shows the different components of LK identified during the data analysis captured in themes. The multiple dimensions of LK form a range of mitigation, coping and adaptation (both structural and non-structural) strategies that enable communities to continue residing in areas exposed to frequent flooding. The crosscutting themes presented in Figure 3 explicitly influence the choice of strategies that are employed at the individual, household and community levels, during different phases of flooding. Since the theme of 'Knowledge of flood hazard' provides an insight into the level of community understanding of flood hazards, it will be discussed first, while other cross-cutting themes will be discussed later on in this section.

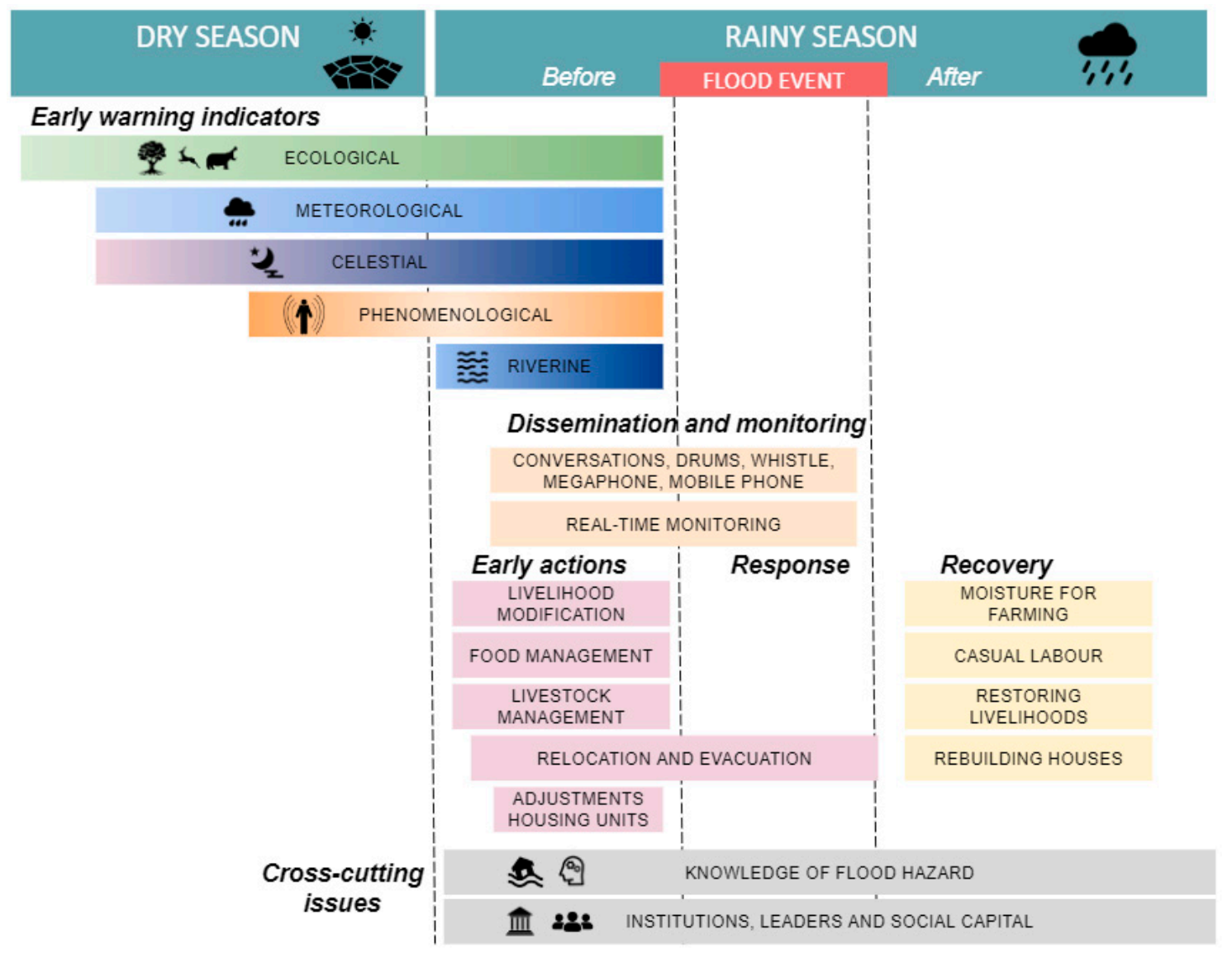

Figure 3. Overview of research results: dimensions of LK for FRM in Malawi. 


\subsection{Crosscutting Theme: Knowledge of Flood Hazards}

Participants differentiated between two types of flooding: fluvial flooding from larger rivers (i.e., Shire and Mwanza) and flash floods from smaller, intermittent, often ephemeral streams. It was emphasised that the flooding situation is exacerbated when smaller streams cannot discharge into the main channel. Another differentiation was between annual flooding (often regarded as being beneficial due to alluvial soils and residual moisture that are important for agricultural activities) and extreme flooding. Floods occur during the rainy season (November to March), and participants pointed out that whilst flooding can be induced by localised rainfall, it frequently occurs as a consequence of upstream rainfall in the Middle and Upper Shire River catchments. According to participants, this often happens during the night, meaning individuals and households are not adequately prepared, and they are more exposed and vulnerable to the negative effects of flooding (e.g., houses collapsing while people are inside and unable to evacuate in time). Across case study communities, it was reported that flash flooding from the Ruo River in January 2015 occurred during the night; thus, it is reasonable to infer that the consulted participants were referring to this event, as their most recent experience. This research did not engage in the analysis of hydro-meteorological data to confirm this statement.

Participants demonstrated a high level of understanding of flood dynamics, by detailing the ways in which waters reach and spread throughout their villages. Based on rainfall intensity and duration, they are able to anticipate how severe flooding will be; for instance, during the FGD with male participants in Kanseche, it was stated that shorter outbursts of rain indicate the flooding of farm fields and roads, whereas prolonged periods of rainfall may also result in the flooding of housing units. Knowledge of the flood extent and flood propagation in villages makes it possible for communities to identify areas within their localities where they can safely evacuate in the case of emergency. Furthermore, participants showed a high level of awareness of differential exposure and vulnerability of certain parts of their communities, often reiterating that households that are located in the lowlands are the ones that are most severely affected.

Participants pointed out a variety of factors and processes perceived as causes of flooding. Of these, environmental degradation was identified as the most influential process, both at the local scale (e.g., clearing of land for farming) and at the wider spatial scale (e.g., deforestation in the highlands). Other factors that are related to hazard characteristics (e.g., rainfall intensity/duration, river network dynamics, siltation, backwater flow), exposure (e.g., geographical location), and vulnerability (e.g., population growth, external interventions) were seen as contributing to flooding. Very seldom, elderly participants connected floods to supra-natural causes (i.e., acts of God). These insights indicate that local people understand the holistic nature of flooding in their villages, caused not merely by waters from nearby rivers, but rather, shaped by a complex interplay between underlying vulnerability factors and processes stemming from outside their immediate geographical locations. Respondents also described their understanding of the complex interplay between the different flooding causes; for example, siltation was identified as a result of the type of vegetation clearance that occurs when population growth forces people to settle and farm next to the river bank.

Participants strongly felt that flood characteristics are changing (increased frequency, extents and impacts), as were the ways in which communities and individuals responded. The key informant from Mbenje elaborated on how some basic flood characteristics are changing, by explaining that they used to know that floods were coming, because waters were arriving in the village gradually, whereas now, waters came 'by surprise', and the whole area was affected within a short timeframe.

\subsection{Local Knowledge before the Flood}

The LK used before a flood was found to be more common than those used during or after a flood. This category is composed of three main components of LK on: (i) local early warning systems, (ii) early action, and (iii) risk reduction strategies. 


\subsubsection{Local Early Warning Systems}

In the early stages of data collection, it was evident that local early warning (EW) indicators, indicating upcoming floods, comprise the majority of what communities identify as LK. An example of different indicators are presented in Table 2, classified into five categories: (i) phenomenological indicators (human physical sensation such as hearing, seeing and feeling), (ii) ecological (flora, fauna and non-human related behaviours), (iii) riverine (behaviour and observations of running water bodies), (iv) meteorological (meteorological phenomena such as winds, rainfall and air temperature), and (v) celestial (behaviours of celestial bodies). The classification derived from this study resembles the classification developed by Acharya and Prakash (2018) [59].

The indicators used to foretell flooding by research participants stem from their close relationship with their surrounding environment, and they are embedded in their livelihoods and everyday existence. For instance, farmers have reported the observation of different animal species in the fields; whereas fishermen have identified an increased number of specific fish species as a sign of upcoming floods. Furthermore, some of the animal species reported as foretelling floods are used as a food source (e.g., mice); hence their numbers are keenly observed within the community. Even though the indicators are classified into five categories, people are constantly observing indicators in several of the categories, to form a full image of the possibility of flooding; for example, the male key informant from GVH Misili elaborated how hippos, seen as an ecological indicator of an upcoming flood, are seen in the villages after the villagers have already observed heavy rainfall (meteorological indicator).

Local EW indicators are shared primarily in an informal manner, and participants explained how individuals observe the signs and will 'chat' about them, both within their household and with neighbours. The role of gender was emphasised, and many examples of women educating their children about indicators were mentioned. Indicators are also shared in an opportunistic manner during community gatherings, such as religious ceremonies, funerals, and during meetings of different community groups (e.g., farmer and women groups). In some instances, participants stated that local chiefs and disaster committees will organise special community meetings in order to share the signs and provide advice for households living in the most flood prone areas, indicating a more formal dissemination practice. Importantly, the fieldwork has unveiled that dissemination of early warning information and decisions to take action are not based solely on local EW indicators, but a rather complex triangulation process between locally sourced information and official warning available to communities through different means (e.g., radios, NGOs working in the communities, local government staff). In the Lower Shire Valley, and likely in similar contextual settings, the resulting early warning systems are characterised by this unstructured triangulation process between different knowledge types (i.e., local and scientific knowledge), whereby people use multiple sources of information to assess the situation and make a decision. 
Table 2. Overview and example of different local early warning indicators.

\begin{tabular}{|c|c|c|}
\hline Categories of Local Indicators & Example Signs & Periods of Occurrence \\
\hline Phenomenological & $\begin{array}{l}\text { - } \quad \text { Elderly community members feeling pain in certain body parts } \\
\text { - } \quad \text { Villagers unable to sleep due to increased temperatures }\end{array}$ & $\begin{array}{l}\text { Before the occurrence of heavy rainfall } \\
\text { September-December }\end{array}$ \\
\hline \multirow{4}{*}{ Ecological } & \multicolumn{2}{|l|}{ Fauna } \\
\hline & $\begin{array}{l}\text { - Increased number of ants ('nyerere') in the villages } \\
\text { - Animals (e.g., hippos 'mvuu', crocodiles) migrating from the rivers to the fields } \\
\text { and villages } \\
\text { - } \quad \text { Birds producing a specific sounds (e.g., trumpet bird ' } n \text { 'gombe } n^{\prime} \text { 'gombe') }\end{array}$ & $\begin{array}{l}\text { July-December } \\
\text { December-January } \\
\text { December }\end{array}$ \\
\hline & \multicolumn{2}{|l|}{ Flora } \\
\hline & $\begin{array}{l}\text { - } \quad \text { Tamarind tree ('bwemba') producing an increased number of flowers } \\
\text { - } \quad \text { Increased production of fruits of the mango tree } \\
\text { - } \quad \text { Plenty of bamboo ('bende') growing next to river banks }\end{array}$ & $\begin{array}{l}\text { August-December } \\
\text { July-December } \\
\text { November-January }\end{array}$ \\
\hline Meteorological & $\begin{array}{ll}\text { - } & \text { Rainfall intensity } \\
\text { - } & \text { Strong winds ('mwera') } \\
\text { - } & \text { Rainfall duration } \\
& \left.\text { Hot temperatures (' } n g^{\prime} a m b a^{\prime}\right)\end{array}$ & $\begin{array}{l}\text { October-March } \\
\text { September-January } \\
\text { October-March } \\
\text { August-December }\end{array}$ \\
\hline Celestial & $\begin{array}{l}\text { - Halo around the moon ('chikwa') } \\
\text { - } \quad \text { Occurrence of orion star ('nthanda') } \\
\text { - } \quad \text { Full moon ('phanda') }\end{array}$ & $\begin{array}{l}\text { August-January } \\
\text { October-January } \\
\text { October-December }\end{array}$ \\
\hline Riverine & $\begin{array}{l}\text { - } \quad \text { Sounds of waters in the rivers increasing } \\
\text { - } \quad \text { Colours of waters getting dirty and muddy } \\
\text { - } \quad \text { Rate of water level increase }\end{array}$ & $\begin{array}{l}\text { December-March } \\
\text { October-January } \\
\text { Shortly before the floods }\end{array}$ \\
\hline
\end{tabular}


Across all case study communities, the reliability of local EW indicators was thought to be decreasing, due to a number of factors. For instance, participants stated that climate change is influencing LK through a change in rainfall patterns, which are nowadays being seen as unpredictable, thus undermining peoples' ability to relate the indicators, with occurrences on the ground. Furthermore, population-driven environmental degradation contributes to the perception of decreasing reliability (e.g., excessive cutting off trees commonly used as EW indicators). Moreover, as previously described, some floods occur in the absence of localised rainfall, thereby decreasing the usefulness of LK. Cultural dynamics is another factor that influences the perceived reliability of LK, with some interviewees considering that new approaches and technologies used in other cultures may be better than their local approaches. Official warnings and weather forecasts are changing the way LK is used within communities:

'We are slowly abandoning local knowledge because the weather forecasts tell us that there will be rains this time and it happens, so we are not using local knowledge considering climate change'.

(FGD male Nyanga)

The perceived decreasing reliability of indicators is an impediment for the younger generations accepting the LK, since they cannot relate the signs that they hear about from their parents with what is happening on the ground. Elderly community members were seen as key players in observing the indicators, with younger generations often thought not to pay attention to such indicators, highlighting the intergenerational gap in LK use.

\subsubsection{Early Action}

The term early action in this research refers to the strategies that are taken by individuals and communities to prepare for and to minimise the impacts of floods upon observing local early warning indicators. A range of strategies that can be classified as early action was identified (Table 3), covering both coping (i.e., short-term local adjustments, risk absorption) and adaptation (i.e., longer-term local changes, risk reduction) strategies [85].The diversity of strategies illustrates that local people can do a great deal to reduce the negative impacts of floods, and across the case studies, participants stated that those who act proactively are the ones that are less affected by floods. It is important to emphasise that the findings indicate that early action at the local level is based not only on the local EW indicators, but rather after an informal triangulation process, between the locally observed indicators and the official information reaching the communities.

Even though the empirical evidence from Table 3 indicates various strategies, data analysis revealed that taking early action is not a community-wide trait, and many individuals and households often decide not to take any anticipatory action. The data showed that factors influencing the lack of early action primarily relate to how the early warning is understood and perceived, as well as the access to resources and livelihoods. In terms of perceptions, the uncertainty associated with early warning information often appears to hinder action, because 'people want to see with their own eyes that they are being affected' (GVH Nyanga). Furthermore, some individuals feel that it might not be worthwhile to move their belongings to the uplands in case flooding does not occur, while some others have the attitude that they might have enough time to safely evacuate when the floods arrive.

In the context of access to resources, participants explained how certain preventative strategies (e.g., food storage, strengthening houses) are typically not implemented, due to high levels of poverty. Additionally, temporary relocation and early evacuation requires land that is not equally available to all segments of society (e.g., ultra poor, individuals and households with no social networks). This indicates that peoples' capacity to take anticipatory and preventative action is shaped by processes stemming from outside their localities, such as economic and political processes that result in high levels of poverty and limited access to land. Livelihood-related factors show that individuals might be reluctant to take early action, because they do not want to leave their farms unattended. Furthermore, those whose main livelihood is fishing might not want to evacuate early, as they cannot fish in the 
uplands. Finally, people feel a strong sense of attachment to their localities; thus, the option of leaving their home is not seen as viable.

Table 3. Examples of early action.

\begin{tabular}{|c|c|}
\hline Categories of Early Action & Examples \\
\hline Livelihood modification & $\begin{array}{l}\text { - } \quad \text { Farming both in the lowlands and uplands } \\
\text { - } \quad \text { Renting farming plots in the uplands } \\
\text { - } \quad \text { Storing extra seeds for replanting after the floods } \\
\text { - } \quad \text { Planting earlier in the season }\end{array}$ \\
\hline Food management & $\begin{array}{l}\text { - Heading to the maize mills prior to the rainy season } \\
\text { - } \quad \text { Storing extra food } \\
\text { - Keeping food on a raised platform inside the house } \\
\text { ('khungu', 'nsanja', 'tandala') } \\
\text { - } \quad \text { Moving food reserves to houses in uplands }\end{array}$ \\
\hline Livestock management & $\begin{array}{l}\text { - Moving livestock to the uplands } \\
\text { - } \quad \text { Not allowing livestock to graze next to the river banks } \\
\text { - Constructing raised platforms for goats and chickens } \\
\left({ }^{\prime} \mathrm{kraal}^{\prime}\right)\end{array}$ \\
\hline Relocation, early evacuation and temporary shelters & $\begin{array}{l}\text { - Looking for land in the uplands to temporarily relocate } \\
\text { - Constructing raised platforms in the lowlands ('chete', } \\
\text { - } \quad \text { Condanda', 'nsanja') } \\
\text { - } \quad \text { Preparing schools and churches in the uplands ('makumbi') } \\
\text { as temporary shelters }\end{array}$ \\
\hline Adjustments to housing units & $\begin{array}{l}\text { - } \quad \text { Digging the drains around the houses } \\
\text { - Thatching the houses with grass } \\
\text { - } \quad \text { Incorporating plastic sheets inside the roofing system } \\
\text { - } \quad \text { Building temporary dikes } \\
\text { - } \quad \text { of burnt bricks } \\
\text { Foundation strengthening by adding a layer of soil and } \\
\text { mud ('chiguwa') }\end{array}$ \\
\hline
\end{tabular}

\subsubsection{Other Risk Reduction Strategies}

In addition to local EW systems and early action, several other types of strategies were identified. These include property-level measures (e.g., improvement to foundations, raising the foundations, openings in the walls, using palm trees as reinforcement), local spatial planning methods (leaving a buffer zone between a farm and the river, building houses away from the river), and reinforcement of soil and river banks (e.g., check dams to control the flow of the river and manage erosion processes, planting of trees, grass, reeds and shrubs on and close to the river banks). It was noted that these practices were perceived to be effective for reducing the impact of annual flooding.

\subsection{Local Knowledge for during the Flood}

Two major components of LK used during flood events emerged: (i) evacuation procedures and (ii) monitoring and dissemination of warning information.

Canoes carved from locally available trees were mentioned as the most common evacuation means. Canoes are commonly owned by fishermen living in the lowlands and, as emphasised by many, they are individual, and not community property. They are the property of a privileged few, who are described as 'better off' (key informant 19) and they can present a 'booming business' (FGD Tizola), as canoe owners might expect payment for aiding evacuation, with the obvious outcome that some of the most vulnerable community members may be unable to evacuate via this means. Other evacuation means mentioned were wooden boats with no engines, walking, ox-carts, bicycles, water plants, and locally available materials such as banana trunks, reeds, or grass doors. Once evacuated, some people stay in temporary shelters in the uplands, either pre-built or built upon arrival, whilst 
others evacuate to schools, churches, tents provided by NGOs or permanent evacuation structures. Some will seek shelter with friends and relatives in neighbouring villages, whilst those who get caught in floods opt for a more 'ad hoc' solutions, such as finding temporary shelter in trees and anthills.

Community members also report creative ways to monitor local flood conditions in real time, including the rates of increase in water levels, debris content, the colour of the waters, foaming and the sounds that the water makes. Many use reeds to measure the water levels, and based on the readings, they will make a decision to stay or to leave their homes. In some of the case studies, participants explained that conditions are monitored by using community-based early warning systems (CB-EWS) installed by NGOs. Yet again, examples of triangulation between different methods were discovered, e.g., participants explained how some would triangulate the information between the reeds and the readings from CB-EWS. In terms of dissemination, the readings were informally shared between community members through conversation, or by using whistles, drums (beaten in a specific way), megaphones, or mobile phones.

\subsection{Local Knowledge for after the Flood}

LK used after flooding primarily consists of strategies that are employed by local communities to rebuild damaged houses, restore livelihoods, and other strategies to aid recovery. Interestingly, the results indicate that houses are typically rebuilt in the same locations. Participants explained that once a house has fallen, the ground is elevated, thus allowing for the construction of a house on raised ground. Furthermore, rebuilding a house in a different location requires new land, which is problematic for people already living in poverty. Generally, houses are rebuilt in the same manner with marginal improvements (e.g., strengthening the walls). In the words of a male FGD participant from GVH Mmodzi, 'you might change the method of construction if you have money. If not, you just build with mud bricks.'

Whilst waiting to rebuild the houses, people stay in temporary shelters, typically built out of grass ('makumbi'), and located in the lowlands. According to the participants, the main priority was to return to farming to take advantage of residual moisture. After the floods have receded, people would wait for the mud to dry up, and then prepare their fields and plant.

Participants stated that the losses are difficult to replace, especially the livestock, given the high levels of poverty. In order to generate income and recover faster, it was reported that individuals would become involved in casual labour, typically working on other peoples' farms. Through this activity, they earned the money to aid recovery (e.g., for buying seeds to plant the fields). Before NGOs and government came to the village with relief aid, communities relied on each other. Female participants from GVH Kanseche explained how those who had lost their food would buy small portions of food from other community members to sustain themselves before help arrived.

\subsection{Crosscutting Themes: Roles of Institutions, Leaders, and Social Capital}

Several local institutions were identified as playing an active role in FRM at the local level. These were primarily Village Civil Protection Committees (VCPCs), Area Civil Protection Committees (ACPCs), religious institutions, and community-based organisations. Community-based civil protection committees (i.e., VCPCs and ACPCs) are at the forefront of flood-related activities, and they serve as a mediator between the community at large and the external stakeholders involved in disaster risk reduction (i.e., NGOs and the government). Whilst the establishment of the committees provides a structure for facilitating DRR at local levels, several challenges were identified, namely: (i) the committees being functional only in areas where the NGO projects are active, (ii) the lack of training and the clear division of responsibilities, (iii) the sustainability of committee interventions outside of the project span and (iv) the power relations involved with a selection of committee members, leading to elite-capture. In addition to the local institutions, traditional leaders (i.e., chiefs) are at the forefront of the community development efforts [86], and they present an essential part of local-level governance. 
The roles of the local institutions and the chiefs are presented in Table 4 . As can be observed, both the local leaders and institutions are involved in various aspects, and their roles are across the FRM cycle.

With regards to social capital, the participants explained that social networks are often utilised, with good examples being: community members assisting each other to strengthen houses, relocating livestock to relatives and friends in neighbouring villages, borrowing canoes from neighbouring villages, helping each other during evacuations, and seeking shelter with relatives or fellow community members. In some instances, research participants explained that they could not rely on fellow community members, mainly because they were also affected, and often lacked the capacity to help themselves, let alone others.

Table 4. The role of local-level institutions and traditional leaders.

\begin{tabular}{|c|c|}
\hline Local Level Institutions and Traditional Leadership & Example Activities in Flood Risk Management \\
\hline Village and area civil protection committees & $\begin{array}{l}\text { - } \quad \text { Committee members as interpreters of local early } \\
\text { - } \quad \text { Awarning indicators } \\
\text { - } \quad \text { Parning information } \\
\text { - } \quad \text { Negotiating land for temporary relocation } \\
\text { - } \quad \text { Warning dissemination } \\
\text { - } \quad \text { Coordination with external stakeholders } \\
\text { (government, NGOs) } \\
\text { - } \quad \text { Encouragement for tree planting }\end{array}$ \\
\hline Religious institutions & $\begin{array}{l}\text { - } \quad \text { Awareness-raising during religious ceremonies } \\
\text { - } \quad \text { Churches as evacuation locations } \\
\text { - Helping religious institution members with recovery }\end{array}$ \\
\hline Community-based organisations & $\begin{array}{l}\text { - Youth clubs developing theatre dramas on flooding to } \\
\text { - } \quad \text { Assisting as a risk communication tool } \\
\text { - } \quad \text { Assisting in afforestation initiatives }\end{array}$ \\
\hline Traditional leaders (i.e., chiefs) & $\begin{array}{ll}\text { - } & \text { Knowledge holders and communicators } \\
\text { - } & \text { Warning dissemination through organising meetings } \\
\text { - } & \text { Evacuation leaders } \\
\text { - } & \text { Facilitating stakeholder collaboration } \\
\text { - } & \text { Land provision } \\
\text { Providing advisory services to community members }\end{array}$ \\
\hline
\end{tabular}

\section{Discussion and Conclusions}

The research was set out with the overall aim of critically examining the importance of LK for FRM in the Lower Shire Valley in Malawi. The general findings indicate that local communities have a sophisticated and complex knowledge system that assists them in dealing with flooding in their localities. This knowledge cuts across different stages of the FRM cycle, and presents an inherent component of community resilience towards natural hazards. The empirical evidence generated here presents the first instance of comprehensive academic research on LK for FRM in Malawi, and it fills a recognised gap in the literature for identifying and documenting LK, e.g., [37]. This research provides evidence from the ground up that can foster thinking among the other FRM actors in Malawi with regard to how they could possibly include LK in their interventions.

\subsection{Content of LK for FRM in Malawi}

The findings reveal that LK comprises more than easily accessible technical aspects (e.g., local construction methods), and includes intangible aspects of social dynamics (e.g., the role of local governance systems and informal communication means). Another important aspect relating to the content of LK is its locally bound character. Findings from this research indicate that LK differs from community to community, even though similar patterns can be observed. For instance, ecological early 
warning indicators exhibit local characteristics, but they are based on similar descriptive behaviours of flora and fauna. Hence, using the LK dimensions presented in this research can serve as a blueprint for the documentation of LK by stakeholders who are involved in community-based work.

LK documentation and its related activities by external stakeholders requires a careful approach, as a full understanding of the complexity of LK and its meaningful integration requires extensive community participation and a full consideration of the local realities. Previous research in Malawi $[47,53]$ indicates that this participation and consideration does not always occur. Insights from the literature indicate that not taking LK on board (which is facilitated through community participation), runs the risk of discipline-centric approaches, in which outsiders to communities decide what constitutes valuable knowledge [87], often resulting in LK being considered as inferior to scientific and practical approaches. The research reported herein indicates that LK is a multi-layered and complex concept, which needs continued community involvement to realise its true benefits. This sends a strong message that existing approaches need to be rethought and redesigned in a manner that will create a platform for local people to participate in, thus contributing their own LK.

\subsection{The Critical Outlook on LK}

The results of this research reveal that LK and its use have both socio-economic and political dimensions. Different aspects of LK are not equally accessible to all; rather, they are conditioned by access to resources (e.g., community members who cannot store food in anticipation of floods, or who lack access to land), and positions within society (e.g., being members of local civil protection committees). In addition, LK is not equally distributed within communities-for instance, farmers have different types of knowledge to fishermen - and there are clear intergenerational and gendered differences in LK use. This aligns with the findings of Pottier [88], who argued that LK cannot be discussed without engaging with its social, economic and political dimensions. The existing approach taken by donors and project implementers (labelled as 'community-based') needs to fully engage with the dynamic and power-relations-conditioned concept of community [76], if LK is to be meaningfully integrated.

Although this research shows that LK is a valuable resource, it has also highlighted the very real need for critical assessment, in which LK is not romanticised and depoliticised, but is rather seen in the context of social realities at the local level [89]. This research has revealed additional arguments for looking at LK critically. Firstly, the fact that people have LK does not mean that they will use it and act on it. Second, it is apparent that LK is a changing concept, and that local people, as knowledge holders, perceive the changing nature of flooding, thus making their LK less reliable than previously thought. These changes are connected with larger processes such as environmental degradation, climate change and private interests. For instance, the participants saw the manifestation of climate change as a change in rainfall patterns, which negatively influenced the reliability of local EW indicators; these findings are in line with previous research in different geographical regions [90-93]. Similarly, the participants also emphasised that the increasing magnitudes and frequencies of flood events means that LK might not prove to be as useful in reducing flood impacts in the future. Taking into account that the frequency and intensity of extreme events that are projected to increase in the region [94], it becomes apparent that LK needs to be looked at objectively, fully understanding the limitations that it has in the light of climate change. At the same time however, one of the main characteristics of LK is its adaptability, and whilst climate change will render some LK irrelevant, other LK will adapt and/or emerge as local communities adjust their approaches under the conditions of climate variability $[74,95]$. Yet, an interesting aspect for further investigation would be to understand the adaptation limits of LK under the changing climate, as previous research has identified that the adaptation of social systems to climate change has its limitations [96,97].

Furthermore, new technologies that are brought by development partners (e.g., official warning information and weather forecasts) are changing the way in which LK is perceived and used, with a reported decrease of importance of LK. However, local people do not have enough power to dictate 
where development initiatives are taking place. Thus, it is reasonable to infer that LK is influenced by processes and agendas that stem outside the imminent locations and influences of communities, and that this generates fundamental vulnerabilities.

Rather than uncritically labelling local communities as being resilient, efforts should be placed at tackling the underlying causes of vulnerabilities. Assigning resiliency to vulnerable communities simply because they possess LK can shift the attention away from the social, economic and political inequalities that limit people's capacity to deal with flooding, including their ability to apply different aspects of LK. LK does bring benefits to communities affected by flooding and contributes to resilience, but these benefits are limited, as the underlying causes of flooding and generators of vulnerabilities are beyond their control. Thus, it is important to draw attention to vulnerability paths rather than merely the hazards themselves [98]. These findings add to the global literature on the topic of LK, and are in line with previous research ([26,60]) focusing on LK for floods in Namibia and Bangladesh, respectively.

Keating et al. [99] centralised their conceptualisation of community flood resilience around the five capitals of the Sustainable Livelihoods Framework: human, financial, social, natural, and physical [100]. Indeed, as seen in this paper, LK is a part of these capitals (e.g., knowledge of temporary relocation as a human capital, the role of chiefs as a social capital, using residual moisture as a natural capital, temporary shelters as physical capital, and casual labour as a financial capital). However, taking into account that LK cannot be separated from socio-economic and political realities, it is clear that to achieve the idea of a 'resilient community', there is a need for fundamental changes in economic and political agendas and external inputs. For instance, human capital can be strengthened by awareness-raising campaigns (organised by NGOs and the government) that would empower people to act on their LK and take action; physical capital can be strengthened by establishing robust evacuation structures and improving access to land, whilst financial capital can be strengthened by providing local people with an opportunity to access job markets and to diversify their incomes. Yet again, it is clear that tackling the underlying causes of vulnerability is a strategy that will contribute to community resilience. LK clearly plays a role, and it is an inherent component, but it is not enough by itself.

\subsection{Integration between Local and Scientific Knowledge}

Another important aspect revealed through this research is the dynamism of LK and its hybrid nature, through its constant renegotiation with scientific and outside knowledge. Local people are involved in an informal triangulation process between what is available locally and what is coming to them from the outside. There is a thin and blurred line between the different knowledge types, which is resulting in new forms hybridised knowledge utilised by local people. Local communities are not passive knowledge receivers nor museums of tradition [69], but rather, active knowledge producers. The literature places significant emphasis on discussing the pathways for the integration between local and scientific knowledge e.g., $[7,30]$. This research shows that integration is informally happening on the ground, in an unstructured manner, and led by local people. What is needed is a further understanding of how this negotiation and knowledge production takes place in local communities, and what the enabling and hindering factors in this process are. It opens questions on who has the capacity and access to integrate. It also indicates that LK needs to be seen as a dynamic concept, and that views in which LK is depicted as static and 'ancestral' are unhelpful and can lead to further marginalisation. Taking into account the fact that local communities are exposed to unprecedented challenges outside their lived experience, and that their LK is constructed based on their experiences, there is a necessity to devise ways in which scientific knowledge (SK) can be coupled with LK. The literature argues that the integration of LK and SK is especially relevant in light of global changes (e.g., climate change, environmental degradation) $[35,90]$, and the implications of global change on LK were also reported in this research. If a problem of project sustainability in the Lower Shire communities is to be improved [47], this integration needs to be done, not at the expense of LK (i.e., by giving more importance to SK), but rather, by taking it as an equally important component in reducing risks at local levels. 


\subsection{Towards the Enhanced Role of LK in FRM in Malawi}

Local people have sophisticated levels of understanding of flooding, with this knowledge presenting a valuable resource for other FRM stakeholders [101]. The diversity of the identified LK in this research highlights that local practices should not be overlooked in approaches that are taken by NGOs and governments, but should be built upon and used to complement the dominant practices. As argued by Scolobig et al. [18], people-centred approaches, in which local communities are encouraged to contribute their knowledge, facilitate the delivery of sustainable FRM. While the importance of LK is partly acknowledged in the National Disaster Risk Management Policy, especially in relation to risk assessment and early warning [54], there are no guidelines on how its role could be enhanced. These types of general recommendations for the use of LK in policy do not result in concrete and tangible outcomes on the ground [102]. Based on a critical assessment of the reality of the LK presented, this paper proposes several venues that would enhance the role of LK in FRM in Malawi.

Rethinking the ways in which communities are involved in FRM presents a first and crucial step for increasing the role of $\operatorname{LK}[7,23,32,34,39]$. In Malawi, there is a need to expand on the participation concept, from the mere consultation of a few community members (very often local elites), to creating an enabling environment in which the heterogeneity of LK could be accounted for. This could be done by introducing more transparency in the selection of Village Civil Protection Committees, while ensuring the representation of various community groups (e.g., elderly people, identified as main knowledge holders). These groups could then lead the process of documentation, an important step in making LK, often available only in verbal form, accessible to the NGOs and government bodies implementing FRM projects in these communities. Documentation would also serve as basis for a process of validation, where LK could be tested in real-time (e.g., monitoring whether local EW indicators translate to a situation on the ground). Documentation and the validation of LK would also contribute to building an evidence-base for the effectiveness of LK, which has been much called for in DRR literature (e.g., [22,61]). Such an evidence base could also serve as a database for finding scientific explanations for some of the LK (e.g., why/if the increased flowering of a certain tree indicates heavy rainfall), which itself could help in building wider confidence in LK [103].

Improved participation would create a space for a dialogue between local communities and external stakeholders [90], which is seen as an important aspect of integration between LK and SK for DRR [7,32,39]. In this space, similarities and differences between LK and SK could be discussed, followed by integrated local-level FRM strategies. For instance, in Malawi, local governments and NGOs, when disseminating seasonal forecasts in meetings with communities, can use this opportunity to gather local indicators of the upcoming season. This would allow for the creation of a co-produced form of information, previously highlighted as being crucial in appreciating the uncertainty that is related to both LK and SK [23]. Existing tools, such as the Participatory Scenario Planning (PSP) could prove valuable in this endeavour [104]. Furthermore, integration could be done in a very pragmatic manner; for example, by improving local construction methods (e.g., dikes made out of local materials) by helping out with the design and provision of materials (e.g., cement).

Finally, for providing a bigger space for LK in FRM in Malawi, there is a need for action by multiple stakeholders. In their roadmap for integrating knowledge, actions and stakeholders, Gaillard and Mercer [39] emphasise both the roles of inside actors (i.e., communities) and outside actors (i.e., scientists, government and NGOs) who are involved, through top-down and bottom-up initiatives. In Malawi, communities could be instrumental in documenting and validating the knowledge, together with the support of NGOs who are recognised as being well-placed in implementing DRR at community levels in developing countries [105]. Local universities could then conduct research on the topics, thus further generating evidence. The policy role rests with the government.

\subsection{Research Limitations}

The limitations of this research were primarily concerned with the methodologies used for data collection. Qualitative methods, chosen as the primary data collection tools, use language as a principal 
tool of knowledge transmission, whereas in reality, not all LK can be put in words, since it is often a part of daily life, and embedded in practices and tacit [35,88]. However, in preparation for FGDs and KIIs, every effort was made to design questions in a manner that would allow for the documentation of multiple aspects of LK. Furthermore, local facilitators were used, in order to bridge the language barrier, and to build trust between community members. Finally, various data-collection instruments (i.e., FGDs, KIIs and observations during field visits) allowed for the triangulation of findings.

\subsection{Final Thoughts}

The research reported herein has uncovered the importance of LK for FRM in the Malawian context, by documenting available knowledge, and by critically assessing its role in the context of FRM. Taking into account the increased interest in LK in both disaster research and practice, this further understanding of the dynamics surrounding LK provides a valuable addition to the literature. This study is especially relevant for NGOs and local governments that are involved in community-based flood risk management in Malawi. The results serve as evidence that approaching the topic of LK needs to be done in an informed manner, and by designing fully participatory approaches that would take into account the heterogeneity of LK, both in its content, and in its distribution within the community. The dimensions of LK that are documented through this research offer insights to stakeholders into what constitutes LK. Furthermore, by considering the complexities of LK that are presented in this research, the ways in which FRM is implemented at the community level in Malawi can be rethought, especially regarding the integration of new approaches with existing strategies that are commonly found in communities. Although this research was based on a Malawian case study, the findings that point to its realities can be useful for researching the topic in different contexts.

Supplementary Materials: The following are available online at http:/ /www.mdpi.com/2071-1050/11/6/1681/ s1.

Author Contributions: R.Š.T. conceived the original concept under the close supervision of G.B.W., A.J.A. and M.J.D., M.J.C.v.d.H. was heavily involved in discussions on parts of the manuscript related to early warning and early action, and designed the figures in the manuscript. F.D.M. and J.M. assisted with research activities in Malawi. R.Š.T. drafted the manuscript. All co-authors revised the manuscript critically for important intellectual content, providing suggestions and comments. All of the authors read and approved the final manuscript.

Funding: This research was funded by the Scottish Government through the Hydro Nation PhD Scholarship awarded to the first author.

Acknowledgments: The authors wish to thank all of the individuals that volunteered their time to take part in this study. Furthermore, we wish to thank all of the research assistants. The authors thank the Scottish Government for funding this research through the Hydro Nation Scholarship. Finally, we wish to thank the three anonymous reviewers whose comments greatly improved the quality of the manuscript.

Conflicts of Interest: The authors declare no conflict of interest.

\section{References}

1. O'Keefe, P.; Westgate, K.; Wisner, B. Taking the naturalness out of natural disasters. Nature 1976, $260,566-567$. [CrossRef]

2. $\quad$ Blaikie, P.; Cannon, T.; Davis, I.; Wisner, B. At Risk: Natural Hazards, People's Vulnerability and Disasters, 1st ed.; Routlege: London, UK, 1994.

3. Wisner, B.; Blaikie, P.; Cannon, T.; Davis, I. At Risk: Natural Hazards, People's Vulnerability and Disasters, 2nd ed.; Routledge: London, UK, 2004.

4. Hallegatte, S.; Vogt-Schilb, A.; Bangalore, M.; Rozenberg, J. Unbreakable: Building the Resilience of the Poor in the Face of Natural Disasters; The World Bank: Washington, DC, USA, 2016; ISBN 978-1-4648-1003-9.

5. Shepherd, A.; Mitchell, T.; Lewis, K.; Lenhardt, A.; Jones, L.; Scott, L.; Muir-Wood, R. The Geography of Poverty, Disasters and Climate Extremes in 2030; Overseas Development Institute: London, UK, 2013; p. 88.

6. Cuny, F.C. Living with floods: Alternatives for riverine flood mitigation. Land Use Policy 1991, 8, 331-342. [CrossRef] 
7. Hiwasaki, L.; Luna, E.; Syamsidik; Shaw, R. Process for integrating local and indigenous knowledge with science for hydro-meteorological disaster risk reduction and climate change adaptation in coastal and small island communities. Int. J. Disaster Risk Reduct. 2014, 10, 15-27. [CrossRef]

8. Kelman, I.; Mercer, J.; Gaillard, J. Indigenous knowledge and disaster risk reduction. Geography 2012, 97, $12-21$.

9. Nyong, A.; Adesina, F.; Osman Elasha, B. The value of indigenous knowledge in climate change mitigation and adaptation strategies in the African Sahel. Mitig. Adapt. Strateg. Glob. Change 2007, 12, 787-797. [CrossRef]

10. Wisner, B.; Gaillard, J.C.; Kelman, I. The Routledge Handbook of Hazards and Disaster Risk Reduction, 1st ed.; Routledge: London, UK, 2012.

11. Iloka, N.G. Indigenous knowledge for disaster risk reduction: An African perspective. Jàmbá J. Disaster Risk Stud. 2016, 8. [CrossRef]

12. Dube, E.; Munsaka, E. The contribution of indigenous knowledge to disaster risk reduction activities in Zimbabwe: A big call to practitioners. Jàmbá J. Disaster Risk Stud. 2018, 10, 8. [CrossRef]

13. Tran, P.; Shaw, R.; Chantry, G.; Norton, J. GIS and local knowledge in disaster management: A case study of flood risk mapping in Viet Nam. Disasters 2009, 33, 152-169. [CrossRef]

14. Maskrey, A. Disaster Mitigation: A Community Based Approach; Development Guidelines; Oxfam: Oxford, UK, 1989; ISBN 978-0-85598-122-8.

15. Chambers, R. Whose Reality Counts? Practical Action Publishing: Rugby, UK, 1997; ISBN 978-1-85339-386-0.

16. Anderson, M.B.; Woodrow, P.J. Rising from the Ashes: Development Strategies in Times of Disaster; Westview Press [u.a.]: Boulder, CO, USA, 1989; ISBN 978-92-3-102618-8.

17. Few, R. Flooding, vulnerability and coping strategies: Local responses to a global threat. Prog. Dev. Stud. 2003, 3, 43-58. [CrossRef]

18. Scolobig, A.; Prior, T.; Schröter, D.; Jörin, J.; Patt, A. Towards people-centred approaches for effective disaster risk management: Balancing rhetoric with reality. Int. J. Disaster Risk Reduct. 2015, 12, 202-212. [CrossRef]

19. Alexander, C.; Bynum, N.; Johnson, E.; King, U.; Mustonen, T.; Neofotis, P.; Oettlé, N.; Rosenzweig, C.; Sakakibara, C.; Shadrin, V.; et al. Linking Indigenous and Scientific Knowledge of Climate Change. BioScience 2011, 61, 477-484. [CrossRef]

20. Shaw, R.; Sharma, A.; Takeuchi, Y. Introduction: Indigenous knowledge and disaster risk reduction. In Indigenous Knowledge and Disaster Risk Reduction: From Practice to Policy; Shaw, R., Sharma, A., Takeuchi, Y., Eds.; Nova Science Publishers: New York City, NY, USA, 2009; pp. 1-13, ISBN 978-1-60741-574-9.

21. Gaillard, J.-C.; Clavé, E.; Vibert, O.; Azhari; Dedi; Denain, J.-C.; Efendi, Y.; Grancher, D.; Liamzon, C.C.; Sari, D.R.; et al. Ethnic groups' response to the 26 December 2004 earthquake and tsunami in Aceh, Indonesia. Nat. Hazards 2008, 47, 17-38. [CrossRef]

22. Dekens, J. Local Knowledge for Disaster Preparedness: A Literature Review; International Centre for Integrated Mountain Development: Patan, Nepal, 2007.

23. Kniveton, D.; Visman, E.; Tall, A.; Diop, M.; Ewbank, R.; Njoroge, E.; Pearson, L. Dealing with uncertainty: Integrating local and scientific knowledge of the climate and weather. Disasters 2015, 39, 35-53. [CrossRef] [PubMed]

24. Smith, T.A. Local Knowledge in Development (Geography). Geogr. Compass 2011, 5, 595-609. [CrossRef]

25. Briggs, J. The use of indigenous knowledge in development: Problems and challenges. Prog. Dev. Stud. 2005, 5, 99-114. [CrossRef]

26. Hooli, L.J. Resilience of the poorest: Coping strategies and indigenous knowledge of living with the floods in Northern Namibia. Reg. Environ. Chang. 2016, 16, 695-707. [CrossRef]

27. Blaikie, P.; Brown, K.; Stocking, M.; Tang, L.; Dixon, P.; Sillitoe, P. Knowledge in action: Local knowledge as a development resource and barriers to its incorporation in natural resource research and development. Agric. Syst. 1997, 55, 217-237. [CrossRef]

28. United Nations Development Programme. Indigenous Knowledge in Disaster Management in Africa; United Nations Development Programme: New York City, NY, USA, 2008.

29. Walshe, R.A.; Nunn, P.D. Integration of indigenous knowledge and disaster risk reduction: A case study from Baie Martelli, Pentecost Island, Vanuatu. Int. J. Disaster Risk Sci. 2012, 3, 185-194. [CrossRef]

30. Mercer, J.; Kelman, I.; Taranis, L.; Suchet-Pearson, S. Framework for integrating indigenous and scientific knowledge for disaster risk reduction. Disasters 2010, 34, 214-239. [CrossRef] 
31. Cronin, S.J.; Gaylord, D.R.; Charley, D.; Alloway, B.V.; Wallez, S.; Esau, J.W. Participatory methods of incorporating scientific with traditional knowledge for volcanic hazard management on Ambae Island, Vanuatu. Bull. Volcanol. 2004, 66, 652-668. [CrossRef]

32. Mercer, J.; Kelman, I.; Dekens, J. Integrating indigenous and scientific knowledge for disaster risk reduction. In Indigenous Knowledge and Disaster Risk Reduction: From Pratice to Policy; Shaw, R., Sharma, A., Takeuchi, Y., Eds.; Nova Science Publishers: New York City, NY, USA, 2009; pp. 115-131.

33. Nkomwa, E.C.; Joshua, M.K.; Ngongondo, C.; Monjerezi, M.; Chipungu, F. Assessing indigenous knowledge systems and climate change adaptation strategies in agriculture: A case study of Chagaka Village, Chikhwawa, Southern Malawi. Phys. Chem. Earth Parts ABC 2014, 67-69, 164-172. [CrossRef]

34. Mercer, J.; Kelman, I.; Alfthan, B.; Kurvits, T. Ecosystem-Based Adaptation to Climate Change in Caribbean Small Island Developing States: Integrating Local and External Knowledge. Sustainability 2012, 4, 1908-1932. [CrossRef]

35. Mercer, J. Knowledge and disaster risk reduction. In Handbook of Hazards and Disaster Risk Reduction; Wisner, B., Gaillard, J.C., Kelman, I., Eds.; Routlege: London, UK, 2012; pp. 97-109.

36. Gaillard, J.C.; Mercer, J. From knowledge to action: Bridging gaps in disaster risk reduction. Prog. Hum. Geogr. 2013, 37, 93-114. [CrossRef]

37. Santha, S.D.; Gahana, P.; Aswin, V. Local knowledge, early warning and coastal hazards: Participatory inquiry among fishworkers in Kerala, India. Action Res. 2014, 12, 273-292. [CrossRef]

38. UNISDR. Hyogo Framework for Action 2005-2015: Building the Resilience of Nations and Communities to Disasters; UNISDR: Geneva, Switzerland, 2005; p. 25.

39. UNISDR. Sendai Framework for Disaster Risk Reduction 2015-2030; UNISDR: Geneva, Switzerland, $2015 ;$ p. 37.

40. International Monetary Fund. World Economic Outlook: Challenges to Steady Growth; International Monetary Fund: Washington, DC, USA, 2018.

41. Mwale, F.D.; Adeloye, A.J.; Beevers, L. Quantifying vulnerability of rural communities to flooding in SSA: A contemporary disaster management perspective applied to the Lower Shire Valley, Malawi. Int. J. Disaster Risk Reduct. 2015, 12, 172-187. [CrossRef]

42. Lumumba Mijoni, P.; Izadkhah, Y.O. Management of floods in Malawi: Case study of the Lower Shire River Valley. Disaster Prev. Manag. Int. J. 2009, 18, 490-503. [CrossRef]

43. Government of Malawi. Malawi 2015 Floods Post Disaster Needs Assessment Report; Government of Malawi: Lilongwe, Malawi, 2015.

44. Rudari, R.; Beckers, J.; De Angeli, S.; Rossi, L.; Trasforini, E. Impact of modelling scale on probabilistic flood risk assessment: The Malawi case. In E3S Web of Conferences; Lang, M., Klijn, F., Samuels, P., Eds.; EDP Sciences: Les Ulis, France, 2016; Volume 7, p. 04015.

45. Shela, O.; Thompson, G.; Jere, P.; Annandale, G. Analysis of Lower Shire Floods: A Flood Risk Reduction and Recovery Programme Proposal; Department of Disaster Management Affairs: Lilongwe, Malawi, 2008.

46. Nillson, A.; Shela, O.; Chavula, G. Flood Risk Management Strategy: Mitigation, Preparedness, Response and Recovery; Department of Disaster Management Affairs: Lilongwe, Malawi, 2010.

47. Šakić Trogrlić, R.; Wright, G.B.; Adeloye, A.J.; Duncan, M.J.; Mwale, F. Taking stock of community-based flood risk management in Malawi: Different stakeholders, different perspectives. Environ. Hazards 2018, 17, 107-127. [CrossRef]

48. Manda, M.Z. Where there is no local government: Addressing disaster risk reduction in a small town in Malawi. Environ. Urban. 2014, 26, 586-599. [CrossRef]

49. Kita, S.M. "Government Doesn't Have the Muscle": State, NGOs, Local Politics, and Disaster Risk Governance in Malawi. Risk Hazards Crisis Public Policy 2017, 8, 244-267. [CrossRef]

50. Department of Disaster Management Affairs. Malawi: National progress report on the implementation of the Hyogo Framework of Action; Department of Disaster Management Affairs: Lilongwe, Malawi, 2015.

51. Carby, B. Beyond the community: Integrating local and scientific knowledge in the formal development approval process in Jamaica. Environ. Hazards 2015, 14, 252-269. [CrossRef]

52. Twigg, J. Characteristics of a Disaster-Resilient Community; DFID: London, UK, 2009.

53. Chawawa, N. Why do Smallholder Farmers Insist on Living in Flood Prone Areas? Understanding Self-Perceived Vulnerability and Dynamics of Local Adaptation in Malawi; University of Edinburgh: Edinburgh, UK, 2018.

54. Department of Disaster Management Affairs. National Disaster Risk Management Policy; Department of Disaster Management Affairs: Lilongwe, Malawi, 2015. 
55. Chikwawa District Council. Disaster Contingency Plan 2014-2015; Chikwawa District Council: Chikwawa, Malawi, 2014.

56. Nsanje District Council. Nsanje District Council Contingency Plan 2015-2016; Nsanje District Council: Nsanje, Malawi, 2015.

57. Irfanullah, H.; Motaleb, M.A. Reading Nature's Mind: Disaster management by indigenous peoples of Bangladesh. Indian J. Tradit. Knowl. 2011, 10, 80-90.

58. Hilhorst, D.; Baart, J.; van den Haar, G.; Leeftink, F. Is disaster "normal" for indigenous people? Indigenous knowledge and coping practices. Disaster Prev. Manag. Int. J. 2015, 24, 506-522. [CrossRef]

59. Acharya, A.; Prakash, A. When the river talks to its people: Local knowledge-based flood forecasting in Gandak River basin, India. Environ. Dev. 2018. [CrossRef]

60. Islam, M.R.; Ingham, V.; Hicks, J.; Kelly, E. From coping to adaptation: Flooding and the role of local knowledge in Bangladesh. Int. J. Disaster Risk Reduct. 2018, 28, 531-538. [CrossRef]

61. Mavhura, E.; Manyena, S.B.; Collins, A.E.; Manatsa, D. Indigenous knowledge, coping strategies and resilience to floods in Muzarabani, Zimbabwe. Int. J. Disaster Risk Reduct. 2013, 5, 38-48. [CrossRef]

62. Mafongoya, P.; Ajayi, O.C. Indigenous Knowledge Systems and Climate Change Management in Africa; CTA: Wageningen, The Netherlands, 2017.

63. Mwase, W.; Mtethiwa, A.T.; Makonombera, M. Climate Change adaptation practices for two communities in Southern Malawi. J. Environ. Earth Sci. 2014, 4, 87-93.

64. Chavula, G. A Report on Local Indigenous Knowledge Systems and Practices (LIKSP) in Malawi; Global Water Partnership-Southern Africa: Pretoria, South Africa, 2013.

65. Department of Disaster Management Affairs. Decentralised early warning systems in Malawi; Department of Disaster Management Affairs: Lilongwe, Malawi, 2015.

66. Atkins. Integrated Flood Risk Management Plan for the Shire Basin Project: Inception Report. Available online: https:/ / www.ltsi.co.uk/project/malawi-integrated-flood-risk-management-plan-for-the-shirebasin (accessed on 20 March 2019).

67. Sillitoe, P. The Development of Indigenous Knowledge: A New Applied Anthropology. Curr. Anthropol. 1998, 39, 223-252. [CrossRef]

68. Antweiler, C. Local knowledge theory and methods: an urban model from Indonesia. In Investigating Local Knowledge: New Directions, New Approaches; Bicker, A., Sillitoe, P., Pottier, J., Eds.; ASHGATE: Farnham, UK, 2004; ISBN 0-7546-3230-X.

69. Wisner, B. Local Knowledge and Disaster Risk Reduction: Keynote during the Side Meeting on Indigenous Knowledge. Available online: www.radixonline.org/resources/WisnerLocalKnowledgeDRR_25-6-09.doc (accessed on 20 March 2019).

70. Jacobi, J.; Mathez-Stiefel, S.-L.; Gambon, H.; Rist, S.; Altieri, M. Whose Knowledge, Whose Development? Use and Role of Local and External Knowledge in Agroforestry Projects in Bolivia. Environ. Manag. 2017, 59, 464-476. [CrossRef] [PubMed]

71. Molina, F.G.J. Intergenerational Transmission of Local Knowledge towards River Flooding Risk Reduction and Adaptation: The Experience of Dagupan City, Philippines. In Disaster Governance in Urbanising Asia; Miller, M.A., Douglass, M., Eds.; Springer: Singapore, 2016; pp. 145-176, ISBN 978-981-287-649-2.

72. McAdoo, B.G.; Moore, A.; Baumwoll, J. Indigenous knowledge and the near field population response during the 2007 Solomon Islands tsunami. Nat. Hazards 2009, 48, 73-82. [CrossRef]

73. Agrawal, A. Dismantling the Divide between Indigenous and Scientific Knowledge. Dev. Chang. 1995, 26, 413-439. [CrossRef]

74. Flavier, J.M.; de Jesus, A.; Navarro, C. The regional program for the promotion of indigenous knowledge in Asia. In The Cultural Dimension of Development: Indigenous Knowledge Systems; Warren, D.M., Slikkerveer, L.J., Brokensha, D., Dechering, W.H.J.C., Eds.; Practical Action Publishing: Rugby, Warwickshire, UK, 1995; ISBN 978-1-85339-264-1.

75. Fernando, J.L. NGOs and Production of Indigenous Knowledge under the Condition of Postmodernity. Ann. Am. Acad. Pol. Soc. Sci. 2003, 590, 54-72. [CrossRef]

76. Titz, A.; Cannon, T.; Krüger, F. Uncovering 'Community': Challenging an Elusive Concept in Development and Disaster Related Work. Societies 2018, 8, 71. [CrossRef]

77. Wisner, B.; Luce, H.R. Disaster Vulnerability: Scale, Power and Daily Life. GeoJournal 1993, 30, 127-140. [CrossRef] 
78. Sillitoe, P. Interdisciplinary experiences: Working with indigenous knowledge in development. Interdiscip. Sci. Rev. 2004, 29, 6-23. [CrossRef]

79. Briggs, J.; Sharp, J. Indigenous knowledges and development: A postcolonial caution. Third World Q. 2004, 25, 661-676. [CrossRef]

80. Yin, R.K. Case Study Research: Design and Methods, 5th ed.; SAGE: Los Angeles, CA, USA; London, UK; New Delhi, India; Singapore; Washington, DC, USA, 2014; ISBN 978-1-4522-4256-9.

81. Bryman, A. Social Research Methods, 4th ed.; Oxford Univ. Press: Oxford, UK, 2012; ISBN 978-0-19-958805-3.

82. Department of Disaster Management Affairs. Malawi Hazards and Vulnerability Atlas; Department of Disaster Management Affairs: Lilongwe, Malawi, 2015.

83. QSR International. NVivo Qualitative Data Analysis Software Version 11. 2010. Available online: http:/ / www.qsrinternational.com/nvivo/support-overview/downloads/nvivo-11-for-windows (accessed on 20 March 2019).

84. Forrest, S.; Trell, E.-M.; Woltjer, J. Civil society contributions to local level flood resilience: Before, during and after the 2015 Boxing Day floods in the Upper Calder Valley. Trans. Inst. Br. Geogr. 2018. [CrossRef]

85. Van den Homberg, M.; McQuistan, C. Technology for Climate Justice: A Reporting Framework for Loss and Damage as Part of Key Global Agreements. In Loss and Damage from Climate Change: Concepts, Methods and Policy Options; Mechler, R., Bouwer, L.M., Schinko, T., Surminski, S., Linnerooth-Bayer, J., Eds.; Climate Risk Management, Policy and Governance; Springer International Publishing: Cham, Switzerland, 2019; pp. 513-545, ISBN 978-3-319-72026-5.

86. Kita, S.M. Barriers or enablers? Chiefs, elite capture, disasters, and resettlement in rural Malawi. Disasters 2019, 43, 135-156. [CrossRef]

87. Sillitoe, P. The state of indigenous knowledge in Bangladesh. In Indigenous Knowledge Development in Bangladesh: Present and Future; Sillitoe, P., Ed.; Intermediate Technology Publications Limited: London, UK, 2000; pp. 3-23.

88. Pottier, J. Negotiating local knowledge: An introduction. In Negotiating Local Knowledge: Power and Identity in Development; Pottier, J., Bicker, A., Sillitoe, P., Eds.; Anthropology, Culture and Society; Pluto Press: London, UK, 2003; pp. 1-30.

89. Arce, A.; Fisher, E. Knowledge interfaces and practice of negotiation: Cases from a women's group in Bolivia and an oil refinery in Wales. In Negotiating Local Knowledge: Power and Identity in Development; Pottier, J., Bicker, A., Sillitoe, P., Eds.; Anthropology, Culture and Society; Pluto Press: London, UK, 2003; pp. 74-98.

90. Ton, K.T.; Gaillard, J.C.; Cadag, J.R.; Naing, A. It takes two to tango: Integrating meteorological knowledge and actions for disaster risk reduction. Clim. Dev. 2017, 9, 479-492. [CrossRef]

91. Kagunyu, A.; Wandibba, S.; Wanjohi, J.G. The use of indigenous climate forecasting methods by the pastoralists of Northern Kenya. Pastoralism 2016, 6, 7. [CrossRef]

92. Molina, J.G.J.; Neef, A. Integration of Indigenous Knowledge into Disaster Risk Reduction and Management (DRRM) Policies for Sustainable Development: The Case of the Agta in Casiguran, Philippines. In Sustainable Development and Disaster Risk Reduction; Uitto, J.I., Shaw, R., Eds.; Disaster Risk Reduction; Springer Japan: Tokyo, Japan, 2016; pp. 247-264, ISBN 978-4-431-55078-5.

93. Ngwese, N.M.; Saito, O.; Sato, A.; Boafo, Y.A.; Jasaw, G. Traditional and Local Knowledge Practices for Disaster Risk Reduction in Northern Ghana. Sustainability 2018, 10, 825. [CrossRef]

94. Chidanti-Malunga, J. Adaptive strategies to climate change in Southern Malawi. Phys. Chem. Earth Parts ABC 2011, 36, 1043-1046. [CrossRef]

95. Ogalleh, S.A.; Vogl, C.R.; Eitzinger, J.; Hauser, M. Local Perceptions and Responses to Climate Change and Variability: The Case of Laikipia District, Kenya. Sustainability 2012, 4, 3302-3325. [CrossRef]

96. Dow, K.; Berkhout, F.; Preston, B.L.; Klein, R.J.T.; Midgley, G.; Shaw, M.R. Limits to adaptation. Nat. Clim. Chang. 2013, 3, 305-307. [CrossRef]

97. Klein, R.J.T.; Midgley, G.; Preston, B.L.; Alam, F.G.; Berkhout, F.; Dow, K.; Shaw, M.R. Adaptation Opportunities, Constraints, and Limits. In Climate Change 2014: Impacts, Adaptation, and Vulnerability. Part A: Global and Sectoral Aspects. Contribution of Working Group II to the Fifth Assessment Report of the Intergovernmental Panel on Climate Change; Field, C., Barros, V.R., Dokken, D.J., Mach, K.J., Mastrandrea, M.D., Bilir, T.E., Chatterjee, M., Ebi, K.L., Estrada, Y.O., Genova, R.C., et al., Eds.; Cambridge University Press: Cambridge, UK; New York, NY, USA; pp. 899-943. 
98. Pescaroli, G.; Nones, M.; Galbusera, L.; Alexander, D. Understanding and mitigating cascading crises in the global interconnected system. Int. J. Disaster Risk Reduct. 2018, 30, 159-163. [CrossRef]

99. Keating, A.; Campbell, K.; Szoenyi, M.; McQuistan, C.; Nash, D.; Burer, M. Development and testing of a community flood resilience measurement tool. Nat. Hazards Earth Syst. Sci. 2017, 17, 77-101. [CrossRef]

100. DFID Sustainable Livelihoods Guidance Notes 1999. Available online: https://www.ennonline.net/ dfidsustainableliving (accessed on 20 March 2019).

101. Bracken, L.J.; Oughton, E.A.; Donaldson, A.; Cook, B.; Forrester, J.; Spray, C.; Cinderby, S.; Passmore, D.; Bissett, N. Flood risk management, an approach to managing cross-border hazards. Nat. Hazards 2016, 82, 217-240. [CrossRef]

102. Romero Manrique, D.; Corral, S.; Guimarães Pereira, Â. Climate-related displacements of coastal communities in the Arctic: Engaging traditional knowledge in adaptation strategies and policies. Environ. Sci. Policy 2018, 85, 90-100. [CrossRef]

103. Hiwasaki, L.; Luna, E.; Syamsidik; Shaw, R. Local and Indigenous Knowledge for Community Resilience: Hydro-Meteorological Disaster Risk Reduction and Climate Change Adaptation in Coastal and Small Island Communities; UNESCO: Jakarta, Indonesia, 2014.

104. CARE International. Practical Guide to Participatory Scenario Planning: Seasonal Climate Information for Resilient Decision-Making; CARE International: Kenya, East Africa, 2018.

105. Benson, C.; Twigg, J.; Myers, M. NGO Initiatives in Risk Reduction: An Overview. Disasters 2001, 25, $199-215$. [CrossRef]

(C) 2019 by the authors. Licensee MDPI, Basel, Switzerland. This article is an open access article distributed under the terms and conditions of the Creative Commons Attribution (CC BY) license (http:/ / creativecommons.org/licenses/by/4.0/). 